\title{
Molecular Genetic Perspectives on the Origin of the Lyngngam Tribe of Meghalaya, India
}

\author{
Banrida T. Langstieh ${ }^{1,2 \#}$, Vikrant Kumar ${ }^{1,3 \#}$, Meka Aruna ${ }^{1 \#}$, Alla Govardhan Reddy ${ }^{4}$, \\ Shilpi Dasgupta ${ }^{1}$, Alla Nirmala ${ }^{1}$, Kumarasamy Thangaraj ${ }^{4}$, Lalji Singh ${ }^{4}$, \\ Battini Mohan Reddy ${ }^{1 \dagger}$ \\ ${ }^{1}$ Molecular Anthropology Group, Indian Statistical Institute, Hyderabad, India \\ ${ }^{2}$ Department of Anthropology, North-Eastern Hill University, Shillong, India \\ ${ }^{3}$ Human Genetics Group, Genome Institute of Singapore, Singapore City, Singapore \\ ${ }^{4}$ Centre for Cellular and Molecular Biology, Hyderabad, India \\ Email: langstieh.banrida@gmail.com, kumarv@gis.a-star.edu.sg, aruna.m79@gmail.com, \\ agreddy@ccmb.res.in, shilpidasgupta1@gmail.com, allanirmala@gmail.com, \\ thangs@ccmb.res.in, lalji@ccmb.res.in, ”bmrisi@gmail.com
}

Received July $10^{\text {th }}, 2012$; revised August $22^{\text {nd }}, 2012$; accepted September $10^{\text {th }}, 2012$

\begin{abstract}
Meghalaya, one of the Northeast Indian states, is inhabited by two major tribal clusters, Khasi and Garo. The disputed origin of the Lyngngam tribe of Meghalaya is a result of their geographic distribution, which is sandwiched between that of the above two major tribal clusters. Our earlier analysis of ethnohistoric, linguistic and demographic data suggested the neighbouring Khasi and Garo as the putative parental population(s) of Lyngngam. In this paper, we have investigated the Lyngngam, Garo and all the 7 subtribes of Khasi of Meghalaya using molecular genetic markers-autosomal, Y-chromosome and mtDNA-to explore the possible origin of the Lyngngam tribe. We obtained admixture estimates for Lyngngam versus the putative parental populations. While autosomal STRs and mtDNA results clearly suggest Khasi origin of the Lyngngam, Y-STR distances show greater proximity of Lyngngam to the Garo. Further, the comparative analysis of the Y-Chromosome and mtDNA haplogroup data on relevant Austro-Asiatic and Tibeto-Burman populations from South and Southeast Asia, published by us earlier, clearly exclude the possibility of Lyngngam origin from outside Meghalaya. The molecular genetic evidence in conjunction with the linguistic, demographic and ethno-historic information clearly suggests Khasi origin of the Lyngngam tribe.
\end{abstract}

Keywords: Austro-Asiatics; Admixture; Autosomal STRs; Y-Chromosome Markers; MtDNA HVS-I and II Sequences

\section{Introduction}

One of the most fundamental and unique features of Indian population structure is the division of its population into strictly defined hierarchical endogamous castes, tribes and religious groups (Figure 1) within any particular geographic region and/or linguistic category (Reddy et al., 2010; Malhotra, 1984; Malhotra \& Vasulu, 1993). However, it is the subdivision of each of these castes, tribes and religious groups into a number of endogamous subunits like subcastes or subtribes and the processes involved in this sub-structuring of the Indian population that makes it quite fascinating for population geneticists. Basically, two different models-fission and fusion-can explain this continuous process of subdivision and/or amalgamation/ admixture, although a totally contrasting model especially to negate the process of fission behind formation of subcastes has also been proposed and demonstrated with empirical evidence (Karve, 1961; Karve \& Dandekar, 1951; Karve \& Malhotra, 1968). On the other hand, subsequently, number of investigators have documented situations where in a number of en-

\footnotetext{
*Declaration of Interest: The authors report no declarations of interest.

\#Banrida, Vikrant and Aruna were with us at ISI as Ph.D. students when they participated in this project.

${ }^{\dagger}$ Corresponding author.
}

dogamous subcastes, subtribes and/or breeding isolates have arisen within a single caste or tribe which had a relatively greater genetic affinity among them as compared to other such groups (Malhotra, 1978, 1979; Reddy, 1983, 1984, 2010; Reddy et al., 1995, 1999, 2001a, 2001b, 2001c, 2007; Crawford et al., 2001; Mitchell et al., 2006; Kumar et al., 2004, 2007). A number of different factors and/or processes have been implicated to be responsible for such subdivisions and subsequent maintenance of their endogamy with distinct group identity (Malhotra, 1978, 1979; Reddy, 2010).

Admixture is also a continual process, which occurs over many generations. The correct identification of ancestral populations and the degree of asymmetry in gene flow (sex biased admixture) are important issues in the admixture studies (Chakraborty, 1986). Recent studies indicate the trend of studying ethnic admixture by identifying the patterns of paternal and maternal gene flow and their contribution to the gene pool of the admixed group, which is made possible with the analysis of Y-chromosome (paternal) and mtDNA (maternal) specific markers (Dipierri et al., 1998; Kittles et al., 1999; Kivisild et al., 1999; Kivisild et al., 2002; Kivisild et al., 2003). India offers immense variety of such situations, which continue to fascinate evolutionary anthropologists. The interest in dis- 


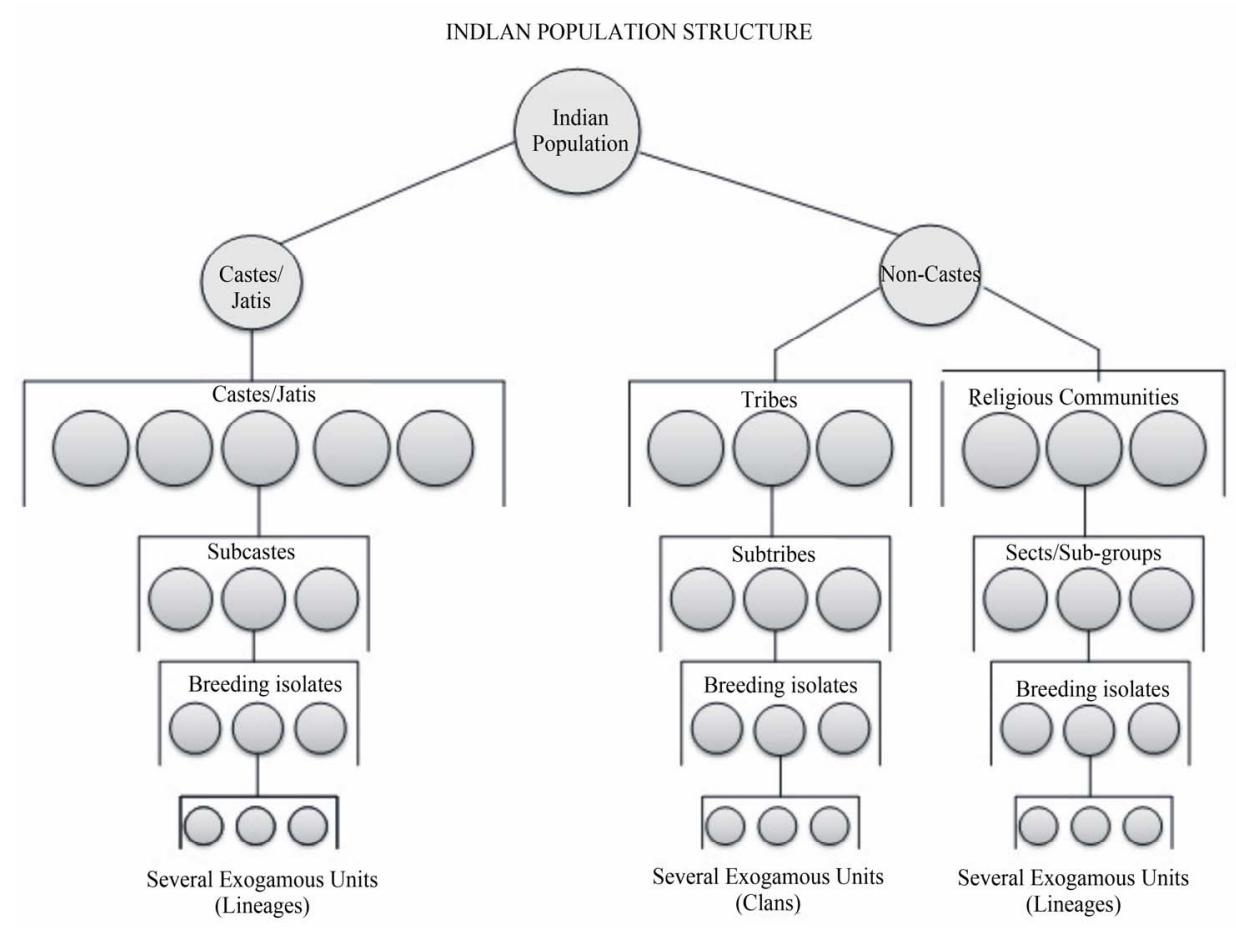

Figure 1.

Schematic diagram depicting essential features of Indian population structure. The exogamous "clans" in tribes are equivalent to "lineages" in the caste and religious groups.

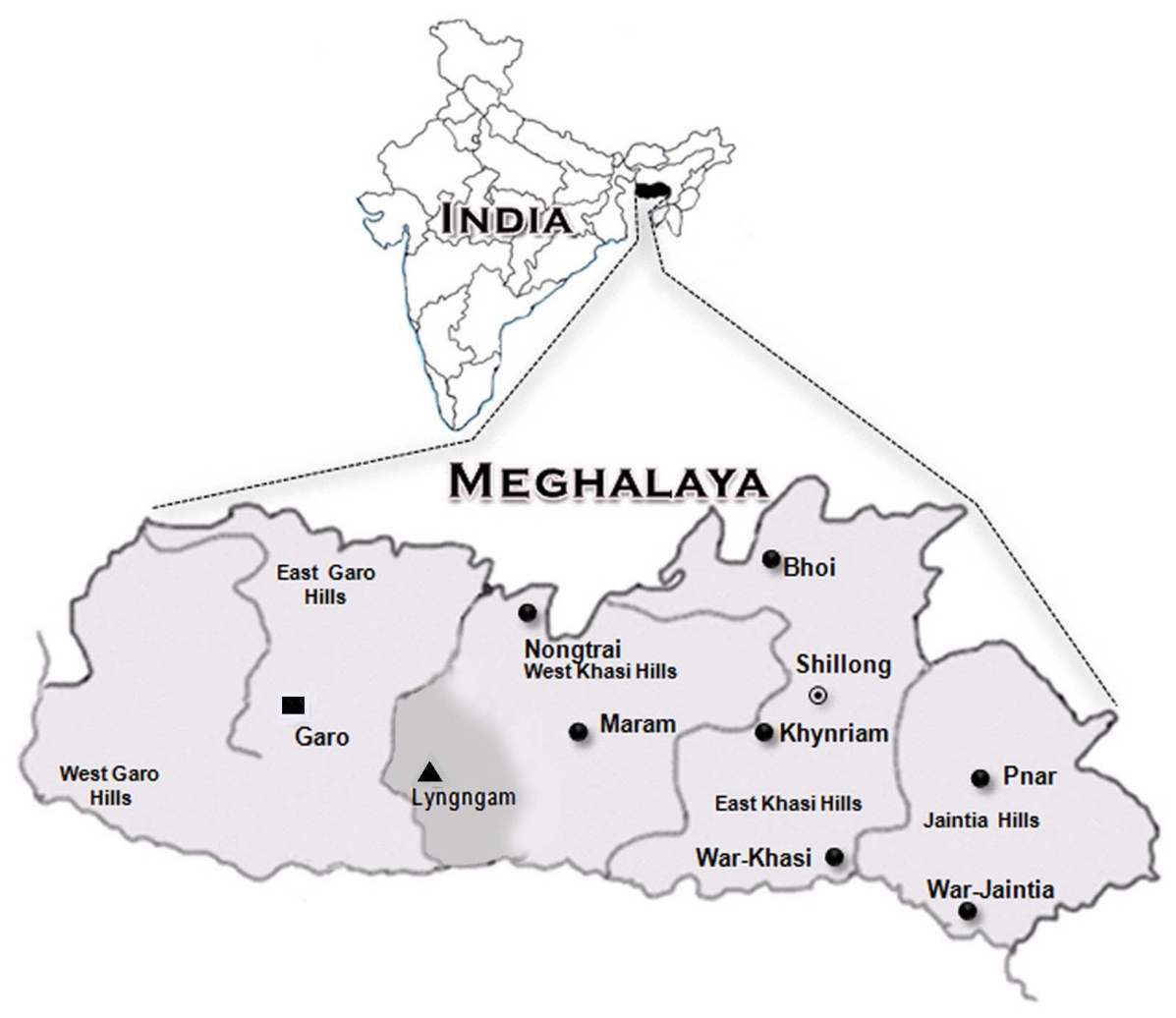

Figure 2.

Location map of Meghalaya showing the core areas of distribution of different sub-tribes of the Khasi, Lyngngam and Garo. Filled circles denote Khasi subtribes, whereas dotted circle denotes the capital of Meghalaya (Shillong). 
secting Indian population structure has therefore been redoubled in recent years, especially with the proliferation of DNA technology and development of rapid screening techniques.

Meghalaya is one of the states of Northeastern India (Figure 2) inhabited mostly by the tribes whose population is $\sim 2,306,069$ (2001 census). Amidst the ethnic majority of populations with East Asian physical features and speaking Tibeto-Burman languages in the northeastern region, while the Khasi represents Khasi-Khmuic (earlier categorized as Mon-Khmer) speakers of the Austro-Asiatic linguistic family (Diffloth, 2005), occupying the central and eastern regions of Meghalaya, the Garo represents Tibeto-Burman speakers of the state, inhabiting the regions towards the west. These are the two overwhelmingly predominant, indigenous and linguistically distinct tribal clusters that inhabit Meghalaya, and follow the system of matrilineal descent and matrilocal residence. These two tribal clusters are found to be genetically also quite distinct (Reddy et al., 2007). Sandwiched between these two linguistically and genetically contrasting populations of Khasi and Garo there is a small tribe of shifting cultivators known as Lyngngam, which inhabits the border areas of west Khasi Hills and South Garo Hills of Meghalaya. Because of its unique geographic position with territorial proximity to both the Khasi and Garo, the origin of the Lyngngam has been disputed, and is claimed to be a subtribe of both the tribes. Based on the prevalent notions, the origin and ethnic position of the Lyngngam can be categorized as follows:

1) Based on the physical features and linguistic similarity, Lyngngam is considered as an Austro-Asiatic group, particularly under the Mon-Khmer subfamily (Gurdon, 1907; Grierson, 1928; Barrett, 1982). The contemporary Khasis therefore consider the Lyngngam as one of the Khasi subtribes (Rodborne, 1977).

2) Bhattacharjee (1978), Sangma (1981) and a majority of the Garos identify the Lyngngam as "Megam", one of the subtribes of the Garo.

3) A mixed/hybrid group (Playfair, 1909; Bareh, 1967; Nongsiang, 1994), culturally intermediate between the Khasis and the Garos (Ehrenfels, 1955). There are only a couple of clans that are unique to Lyngngam, many other clans have affinity with and exogamous to certain clans of either the Khasi or Garo, suggesting probably their evolution from a common ancestor. Likewise, there are similar as well as distinctive socio-cultural features of Lyngngam when compared to the neighbouring Khasi and Garo (Langstieh \& Reddy, 1999, 2004).

4) A distinct tribe, probably with an independent origin, certainly not a sub-tribe of either the Khasi or Garo (Mathur, 1979). The preliminary genetic and dermatoglyphic evidences (Ahmed et al., 1997; Thapa et al., 1998) support the Lyngngam as biologically distinct from both the Khasi and Garo. Concurrent to this most of the informants believe that they were the autochthons of the present habitat in western Meghalaya. The analysis of folk narratives of the Lyngngam, "Kon Bli", suggests that their ancestors were explorers and warriors who came to Meghalaya and defended the land that they presently occupy (Langstieh \& Reddy, 1999, 2004), suggesting probably the independent origin of this tribe.

From the foregoing information, no clear answers emerge regarding origin and ethnic position of the Lyngngam and given the type of available data it was not possible to resolve the issue convincingly. However, based on the linguistic affiliation, it appears that the Lyngngam might have been relatively more akin to the Khasi than to the Garo. The Lexico-Statistical Analysis (Swadesh, 1950, 1951, 1972) of the 200 Lyngngam and the corresponding Khasi words collected by us suggests that although Khasi and Lyngngam both speak the broad KhasiKhmuic language of the Austro-Asiatic family, their speech forms might have been separated around 1500 years ago (CI: $1.69 \mathrm{M}-2.09 \mathrm{M}$ years) from a common speech form (Langstieh, 2003).

Our recent exploratory studies (Langstieh \& Reddy, 1999, 2004) of this small tribe based on demography, ethnohistory, marital networks, clan structure and other population structural measures suggest that Lyngngam as a whole forms an endogamous unit with a population of about 7000 individuals organized into about 1400 households. However, 22\% of the Lyngngam marriages were contracted outside this tribe (Langstieh \& Reddy, 1999, 2004), a great majority of those male spouses coming from the neighbouring Khasi and Garo. The majority of the Khasi contributors to the Lyngngam fold hail from the neighbouring Nongtrai, Maram, War, Bhoi and Khynriam subtribes in the decreasing order of frequency and a great majority of the 29 Lyngngam clans were involved in the exogamous interactions. Further, the Lyngngam clans suggest a relatively greater degree of commonness with the Khasi although a couple of Lyngngam clans could be traced as common with the Garo as well (Langstieh \& Reddy, 1999, 2004). Although the uniquely identified Lyngngam specific clans suggest that they might represent the founding ancestors of this admixed population, given the Austro-Asiatic affinity of the Lyngngam dialect and the names of Lyngngam clans suggest probable Khasi origin of this tribe. Due to its geographic position, this tribe might have later developed marital interactions with the neighboring Tibeto Burman Garos. Given the above scenario, there is strong possibility that the gene pool of the Lyngngam may have distinct genetic signatures from both these putative parental populations (Khasi and Garo), while the former is likely to have overwhelming contribution to the genetic makeup of the Lyngngam. The results based on molecular genetic markers, particularly the uniparental mitochondrial DNA (mtDNA) and Y chromosome (NRY) markers, should reflect these expectations in a more conclusive way. In the present paper, we shall outline the findings based on the analysis of molecular genetic markers-autosomal, mtDNA and Y-chromosome-and test the degree of correspondence between the molecular genetic evidences and the patterns expected from the ethno-historic and demographic information and estimate genetic contributions of different source populations to the gene pool of Lyngngam.

\section{Materials and Methods}

\section{Collection of Blood Samples}

About $5 \mathrm{ml}$ of intravenous blood samples were collected from 515 subjects, after obtaining written informed consent. These subjects represent, besides Lyngngam and Garo, all the 7 subtribes of the Khasi tribe of Meghalaya. The sampled populations and the number of subjects that could be successfully screened for different sets of markers are given in Table 1. As the language of Lyngngam is known to be similar to that of the Khasi, blood samples were also collected from all the 7 subtribes of the Khasi besides the neighboring Garo. This may help examine if Lyngngam has any specific and close relationship 
Table 1.

Sample size, location of study and linguistic affiliation of the 9 tribal populations of Meghalaya of the present study.

\begin{tabular}{|c|c|c|c|c|c|c|c|}
\hline \multirow{2}{*}{ Populations } & \multicolumn{4}{|c|}{ No. of subjects } & \multirow{2}{*}{$\begin{array}{l}\text { Traditional } \\
\text { occupation }\end{array}$} & \multirow{2}{*}{$\begin{array}{l}\text { Distribution in } \\
\text { Meghalaya }\end{array}$} & \multirow{2}{*}{ Linguistic affiliation } \\
\hline & Auto-STRs & Y-STR & HVS-I & HVS-II & & & \\
\hline Lyngngam & 78 & 60 & 82 & 73 & Shifting cultivators & $\begin{array}{c}\text { West Khasi hills } \\
\text { district }\end{array}$ & $\begin{array}{l}\text { Austro-asiatic } \\
\text { (mon-khmer) }\end{array}$ \\
\hline Garo & 64 & 67 & 87 & 89 & $\begin{array}{l}\text { Shifting cultivators \& } \\
\text { Settled agriculturist }\end{array}$ & $\begin{array}{l}\text { South Garo hill } \\
\text { district \& others }\end{array}$ & Tibeto-burman \\
\hline Nongtrai ${ }^{*}$ & 29 & 18 & 29 & 29 & Shifting cultivators & $\begin{array}{c}\text { West Khasi hills } \\
\text { district }\end{array}$ & $\begin{array}{l}\text { Austro-asiatic } \\
\text { (mon-khmer) }\end{array}$ \\
\hline Maram $^{*}$ & 48 & 58 & 72 & 77 & Settled agriculturist & $\begin{array}{c}\text { West Khasi hills } \\
\text { district }\end{array}$ & $\begin{array}{c}\text { Austro-asiatic } \\
\text { (mon-khmer) }\end{array}$ \\
\hline Khynriam $^{*}$ & 73 & 82 & 95 & 100 & Settled agriculturist & $\begin{array}{l}\text { East Khasi hills } \\
\text { district }\end{array}$ & $\begin{array}{c}\text { Austro-asiatic } \\
\text { (mon-khmer) }\end{array}$ \\
\hline Pnar ${ }^{*}$ & 50 & 40 & 53 & 53 & Settled agriculturist & Jaintia hills district & $\begin{array}{l}\text { Austro-asiatic } \\
\text { (mon-khmer) }\end{array}$ \\
\hline Bhoi* & 45 & 32 & 34 & 33 & Shifting cultivators & Ri-Bhoi district & $\begin{array}{l}\text { Austro-asiatic } \\
\text { (mon-khmer) }\end{array}$ \\
\hline War-Khasi ${ }^{*}$ & 38 & 23 & 31 & 27 & Horticulturist & $\begin{array}{l}\text { East Khasi hills } \\
\text { district }\end{array}$ & $\begin{array}{l}\text { Austro-asiatic } \\
\text { (mon-khmer) }\end{array}$ \\
\hline WarJaintia $^{*}$ & 23 & 21 & 22 & 20 & Horticulturist & Jaintia hills district & $\begin{array}{l}\text { Austro-asiatic } \\
\text { (mon-khmer) }\end{array}$ \\
\hline Total & 448 & 401 & 505 & 501 & & & \\
\hline
\end{tabular}

Note: *Dialectical groups of Khasi.

with any of the Khasi subgroups, the evidence that may precisely help trace its origin.

\section{Ethics Statement}

The samples were collected with written informed consent of all the subjects. This study has been approved by the institutional Review Committee for Protection of Research Risks to Humans.

\section{Laboratory Analyses}

DNA was isolated from the above samples following standard protocol (Sambrook et al., 1989). The extracted DNA was quantified by spectrophotometer method followed by verification in $0.8 \%$ agarose gel (Sambrook et al., 1989). AmpFlSTR Profiler Plus kit (ABI, Applied Biosystems, USA) (Applied Biosystems, 2001), which consists of 9 Autosomal STR loci, was amplified as per the manufacturers instructions. Amplified samples were analyzed in ABI 377 automated DNA sequencer and GeneScan and Genotyper softwares (ABI) were used to obtain the allelic designations at the D3S1358, D8S1179, D5S181, vWA, D21S11, D13S317, FGA, D7S820 and D18S5 loci. We have also typed the following 6 Y-STR loci: DYS19, DYS389I, DYS389II, DYS390, DYS391 and DYS393 which were amplified by multiplex PCR and were analyzed on ABI 3730 sequencer. The GENOTYPER software was used to analyze the fragment size. The fragment sizes of the alleles were converted into repeat units as suggested by Butler et al. (2002). Allele length for DYS389b was obtained by subtracting the allele length of DYS389I from DYS389II. Further, mtDNA hypervariable segment I (HVS I) and hypervariable segment II (HVS II) of the mtDNA control region were amplified and sequenced by means of the procedures described in a recent study (Kong et al., 2003). Sequences were edited and mutations scored relative to the revised Cambridge Reference Sequence (Andrews et al., 1999). Even though we have screened these samples for both mtDNA and Y-chromosome SNPs and haplogroups resolved, we have already published these data in an earlier paper (Reddy et al. 2007). The mtDNA sequence data and the STR frequency data can be obtained from the corresponding author on request.

\section{Statistical Methods}

For autosomal and Y-STR markers, the genetic distances were computed using the modified Cavalli-Sforza distance $\left(D_{A}\right)$ measure of Nei et al. (1983). These computations were performed using the NJBAFD program supplied by Dr. Takezaki, National Institute of Genetics, Mishima, Japan. Pairwise $F_{\text {ST }}$ distances were calculated for HVSI and HVSII sequences using Arlequin ver 2.0 (Schneider et al., 2000). In order to assess the role of geographic distance in the genetic relationship between Lyngngam and the surrounding tribes of Meghalaya, we obtained mantel correlations, with the help of MANTEL package (Relethford, 1993), between the geographic distance matrix and the genetic distance matrixes for different pairs of Meghalaya tribes using different sets of DNA markers. Finally, multidimensional scaling (MDS) of the genetic distances and the two dimensional plots of populations in multivariate space were obtained using SPSS version 7. We used Admix 2.0 package 
initially developed by Bertorelle and Excoffier (1998) for two parental populations and extended to any number of parental populations by Dupanloup and Bertorelle (2000), for obtaining the admixture proportions of different putative parental populations.

\section{Results}

\section{Phylogenetic Affinity of Lyngngam to Khasi and Garo}

In order to trace the origin of Lyngngam from among the Meghalaya tribes we examined relative genetic distances of Lyngngam to the Khasi and Garo populations with reference to different sets of genetic markers (Table 2). This was done in two stages, first Lyngngam with the neighboring Khasi, all Khasi and Garo and then Lyngngam with the 7 individual Khasi subtribes and the Garo. It is intriguing to note that while the Lyngngam shows much greater affinity to the Khasi when compared to the Garo in HVS I \&II sequences-based distances as well as in autosomal STR-based distances, it shows greater affinity to the Garo in the Y-STR distances, suggesting dichotomous nature of their genetic relationship to Khasi and Garo. To see if Lyngngam is specifically close to any particular Khasi subgroup, the distance matrices were subjected to multidimensional scaling and the plots based on the first two dimensions are presented in Figure 3. This analysis suggests relative closeness of Lyngngam to the neighboring Bhoi and Khynriam, when compared to the other Khasi tribes as well as to the Garo in the autosomal STRs whereas it shows closer affinity in the decreasing order to the neighboring Nongtrai, Khynriam and Pnar, and Nongtrai, Khynriam and War Khasi, respectively, in case of the HVS I \& II sequences. This pattern is substantiated by the significant mantel correlation obtained between geographic and genetic distance matrices based on HVS I \& II sequences (Table 3). Given matrilineal descent, this may suggest founding of the Lyngngam maternal gene pool predominantly from a common Khasi source, especially since the maternal lineages remain relatively static and the admixture is primarily by way of males moving in from the surrounding populations. However, in case of Y STRs, Lyngngam is relatively closer to the Garo as well as to a few neighboring Khasi tribes viz. Khynriam, Maram and Pnar.

\section{Sharing Pattern of the Lyngngam Y-STR and mtDNA HVS I \& II Haplotypes with other Meghalaya Tribes}

$\mathrm{Y}$ chromosome and mtDNA specific haplotypes are informative about the history of paternal and maternal lineages of a population, respectively, hence useful in tracing the origin of Lyngngam. The relative proportions of sharing of the Lyngngam Y-STR and mtDNA HVS I \& II sequence based haplotypes with those of Khasi and Garo are depicted as pie diagrams (Figure 4), while the haplotype wise sharing pattern is furnished in Supplementary Tables S1-S3. The mutational positions characterizing each haplotype of HVS I \& II are given in Supplementary Tables S4 and S5. Overall, it appears that Khasi contribution to Lyngngam genetic constitution is overwhelmingly greater and more heterogeneous than the Garo, especially with reference to maternal lineages. In case of HVS I, 27 of the 40 haplotypes identified from 82 sequences are found to be Lyngngam specific, while it shares 7 haplotypes exclusively with Khasi and 6 with both the Khasi and Garo. Lyngngam shares no HVS I haplotype exclusively with the Garo. Among the 6 that Lyngngam shares with both Khasi and Garo, haplotype 3 and 7 are very predominantly found among the Garo, while haplotypes 9 and 19 are more widely shared with the Khasi. Of the 7 haplotypes that the Lyngngam exclusively shares with the Khasi, 17 and 38 are more widely found among the latter. Similarly, out of 35 haplotypes identified from the 73 Lyngngam HVS II sequences 20 were found unique to Lyngngam, 10 shared with both the Khasi and Garo and 3 and 2 with Khasi and Garo, respectively. It is interesting to note that nearly $60 \%$ of the Lyngngam samples represent the 10 haplotypes common to both the Khasi and Garo, while another $14 \%$ represent 5 more haplotypes that are found either in Khasi or Garo. Out of these 15, while haplotypes 2, 14 and 25 are widely represented by Khynriam, Nongtrai and Khynriam and Pnar, respectively, haplotypes 1 and 33 are most predominantly found in Garo.

Out of 54 Y-STR haplotypes identified from 60 male samples of Lyngngam, 30 were found to be unique to Lyngngam, while 14 and 7, respectively, were shared with Khasi and Garo. The remaining 3 haplotypes are shared with both Khasi and Garo, suggesting that nearly half of Lyngngam male lineages probably had either Khasi or Garo origin. Although Garo contribution to Lyngngam male lineages outweighs the contribution of any single Khasi subtribe, the overall contributions of the Khasi $(25 \%)$ seems markedly more heterogeneous as well as outweigh the Garo contribution (12\%). This finding is somewhat at variance to the pattern observed on the basis of Y-STR allele frequency based distances in which Lyngngam is relatively closer to Garo. All the 7 subgroups of Khasi share haplotypes with Lyngngam although Khynriam and Bhoi share relatively more haplotypes when compared to others.

\section{Contribution of the Khasi and Garo Tribes of Meghalaya to the Genetic Constitution of Lyngngam}

Using the software Admix2.0, we obtained admixture proportions separately for the 9 autosomal STRs, mtDNA HVS I \& II and 6 Y-STRs. The admixture analysis was structured into 3 categories with Lyngngam assumed to be the hybrid population and 1) Khasi and Garo, 2) "Neighbouring Khasi" (Nongtrai and Maram), "Other Khasi" and Garo and 3) Garo and each of the 7 individual Khasi populations, respectively, as the putative parental populations. The results of each of the three analyses are presented in Table 4. In the first case, the contribution of Khasi is found to be much greater and much more significant to the genetic make up of the Lyngngam, when compared to the Garo in both autosomal STRs ( $82 \%$ against $18 \%$ ) and mtDNA HVS I and HVS II sequence data ( $78 \%$ against $22 \%$ ). Furthermore, it is evident from the results that the contribution of the "neighbouring Khasi" subgroups (Nongtrai and Maram) is relatively much greater than those farther apart namely the "Other Khasi" groups. However, when the individual Khasi populations were considered the contribution of Garo (31\%) in autosomal STRs is shown to be greater than any individual Khasi population; only Maram comes closer (28\%) to the contribution of Garo. Nevertheless, given that the Garo represents the tribe as a whole, the results of comparison with the pooled sample of Khasi would be most apt. The situation is somewhat at variance in the case of mtDNA HVS I \& II, where the neighbouring Nongtrai, one of the Khasi subtribes, contributes disproportionately highly to the genetic constitution of Lyngngam $(\sim 53 \%)$, 
Table 2.

Lyngngam genetic distances with the 3 broad Meghalaya populations.

\begin{tabular}{|c|c|c|c|}
\hline Genetic systems (distance measures) & Garo & Neighboring Khasi & All Khasi \\
\hline Autosomal STRs (Nei's $D_{A}$ ) & 0.073 & 0.062 & 0.044 \\
\hline Y-STRs (Nei's $D_{A}$ ) & 0.052 & 0.066 & 0.066 \\
\hline mtDNA HVS-I (pairwise F FT) & 0.085 & 0.039 & 0.025 \\
\hline mtDNA HVS-II (pairwise $F_{\text {ST }}$ ) & 0.076 & 0.053 & 0.032 \\
\hline
\end{tabular}

Table 3.

Results of Mantel correlations between the distance matrices based on geography and different sets of DNA markers.

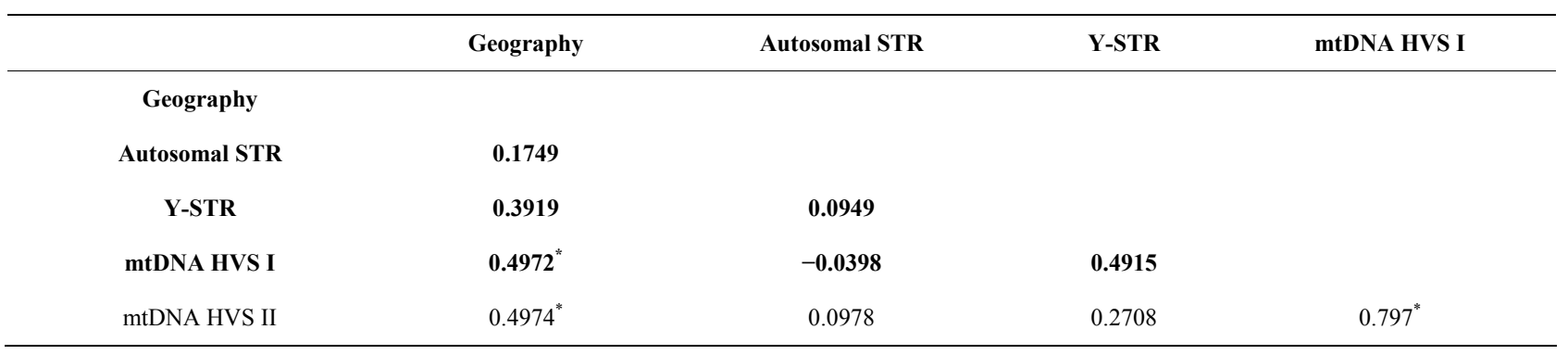

Table 4.

Admixture proportions (m) and their standard deviations (S.D.) for the autosomal STR (9 loci), Y STR (6 loci) and mtDNA HVRS I \& II.

\begin{tabular}{|c|c|c|c|c|c|c|c|c|c|}
\hline \multicolumn{10}{|c|}{ (a) Two parental populations } \\
\hline Pop $^{n}$ & $\mathbf{N}$ & $\begin{array}{c}\text { Autosomal } \\
\text { (m } \mathbf{m} \text { S.D.) }\end{array}$ & $\mathbf{N}$ & $\begin{array}{c}\text { Y chromosomal } \\
(m \pm \text { S.D. })\end{array}$ & $\mathbf{N}$ & $\begin{array}{c}\text { mtDNA } \\
\text { HVS I } \\
(m \pm \text { S.D. })\end{array}$ & $\mathbf{N}$ & $\begin{array}{c}\text { mtDNA } \\
\text { HVS II } \\
(\mathbf{m} \pm \text { S.D. })\end{array}$ & $\begin{array}{c}\text { mtDNA } \\
\text { HVS I+II } \\
(m \pm \text { S.D. })\end{array}$ \\
\hline Khasi & 650 & $0.8151 \pm 0.1310$ & 274 & $0.3220 \pm 0.1895$ & 353 & $0.7794 \pm 0.0726$ & 344 & $0.6052 \pm 0.1000$ & $0.7787 \pm 0.0707$ \\
\hline Garo & 128 & $0.1849 \pm 0.1310$ & 67 & $0.6780 \pm 0.1895$ & 87 & $0.2206 \pm 0.0726$ & 94 & $0.3948 \pm 0.1000$ & $0.2213 \pm 0.0707$ \\
\hline \multicolumn{10}{|c|}{ (b) Three parental populations } \\
\hline Neigh. Khasi & 186 & $0.5122 \pm 0.1395$ & 76 & $0.1607 \pm 1.7581$ & 102 & $0.3971 \pm 0.2294$ & 106 & $0.0984 \pm 0.2137$ & $0.3916 \pm 0.2236$ \\
\hline Other Khasi & 464 & $0.2382 \pm 0.1583$ & 198 & $0.2148 \pm 1.8829$ & 251 & $0.3913 \pm 0.2239$ & 238 & $0.6016 \pm 0.2040$ & $0.3990 \pm 0.2135$ \\
\hline Garo & 128 & $0.2496 \pm 0.1140$ & 67 & $0.6244 \pm 0.3211$ & 87 & $0.2117 \pm 0.0747$ & 94 & $0.3000 \pm 0.1066$ & $0.2094 \pm 0.0730$ \\
\hline \multicolumn{10}{|c|}{ (c) Nine individual Meghalaya populations } \\
\hline Pop $^{n}$ & $\mathbf{N}$ & $\begin{array}{c}\text { Autosomal } \\
\text { (m } \mathbf{m} \text { S.D.) }\end{array}$ & $\mathbf{N}$ & $\begin{array}{c}\text { Y chromosomal } \\
(\mathbf{m} \pm \text { S.D. })\end{array}$ & $\mathbf{N}$ & $\begin{array}{c}\text { mtDNA } \\
\text { HVS I } \\
(\mathbf{m} \pm \text { S.D. })\end{array}$ & $\mathbf{N}$ & $\begin{array}{c}\text { mtDNA } \\
\text { HVS II } \\
(\mathbf{m} \pm \text { S.D. })\end{array}$ & $\begin{array}{c}\text { mtDNA } \\
\text { HVS I + II } \\
(\mathbf{m} \pm \text { S.D. })\end{array}$ \\
\hline Nongtrai & 90 & $0.1850 \pm 0.1354$ & 18 & $0.0467 \pm 1.2817$ & 30 & $0.5231 \pm 0.3005$ & 29 & $0.3925 \pm 0.1928$ & $0.5310 \pm 0.2821$ \\
\hline Maram & 96 & $0.2814 \pm 0.1677$ & 58 & $0.2386 \pm 2.7037$ & 72 & $0.0267 \pm 0.1975$ & 77 & $-0.1624 \pm 0.1372$ & $0.0304 \pm 0.2050$ \\
\hline Khynriam & 146 & $-0.0177 \pm 0.3536$ & 82 & $0.0476 \pm 2.8416$ & 95 & $0.0572 \pm 0.2929$ & 100 & $0.3466 \pm 0.2691$ & $0.0381 \pm 0.2925$ \\
\hline Pnar & 100 & $0.1131 \pm 0.1652$ & 40 & $-0.3932 \pm 3.2148$ & 69 & $0.1160 \pm 0.1481$ & 58 & $0.1266 \pm 0.1972$ & $0.1250 \pm 0.1568$ \\
\hline Bhoi & 90 & $0.1517 \pm 0.3341$ & 32 & $-0.1736 \pm 1.8787$ & 34 & $0.0789 \pm 0.0989$ & 33 & $0.0884 \pm 0.1983$ & $0.0753 \pm 0.0985$ \\
\hline War-Khasi & 82 & $0.0016 \pm 0.1235$ & 23 & $0.1572 \pm 1.2828$ & 31 & $0.0939 \pm 0.1555$ & 27 & $-0.0168 \pm 0.1302$ & $0.0963 \pm 0.1567$ \\
\hline War-Jaintia & 46 & $-0.0216 \pm 0.3448$ & 21 & $0.2828 \pm 1.0826$ & 22 & $-0.0005 \pm 0.0425$ & 20 & $0.0742 \pm 0.0850$ & $0.0001 \pm 0.0423$ \\
\hline Garo & 128 & $0.3065 \pm 0.1824$ & 67 & $0.7939 \pm 1.6881$ & 87 & $0.1047 \pm 0.1544$ & 94 & $0.1509 \pm 0.1380$ & $0.1039 \pm 0.1436$ \\
\hline
\end{tabular}

Note: ${ }^{*} \mathrm{~N}=$ Sample size. 


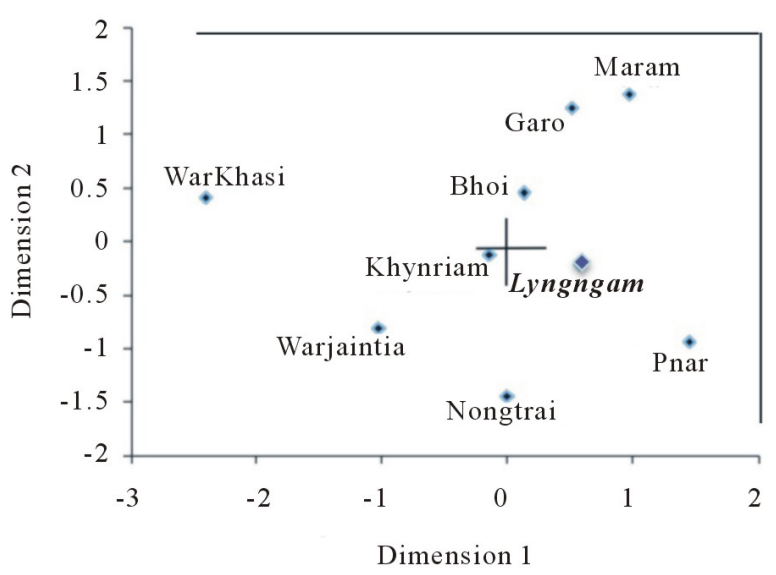

(a)

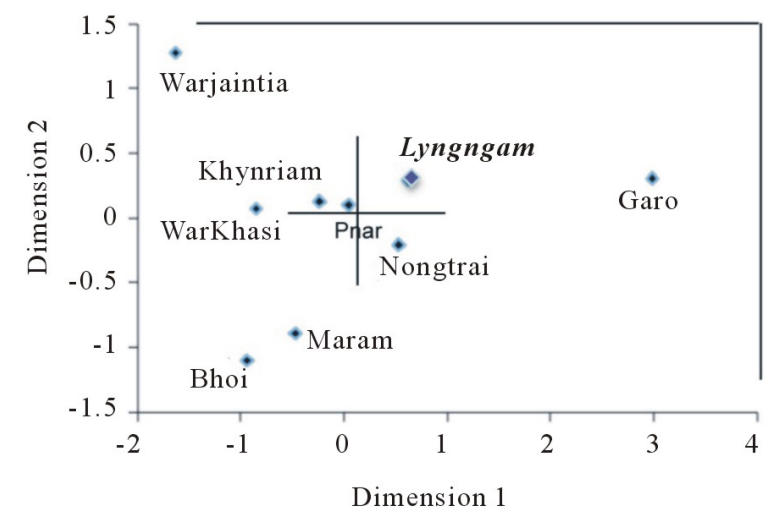

(c)

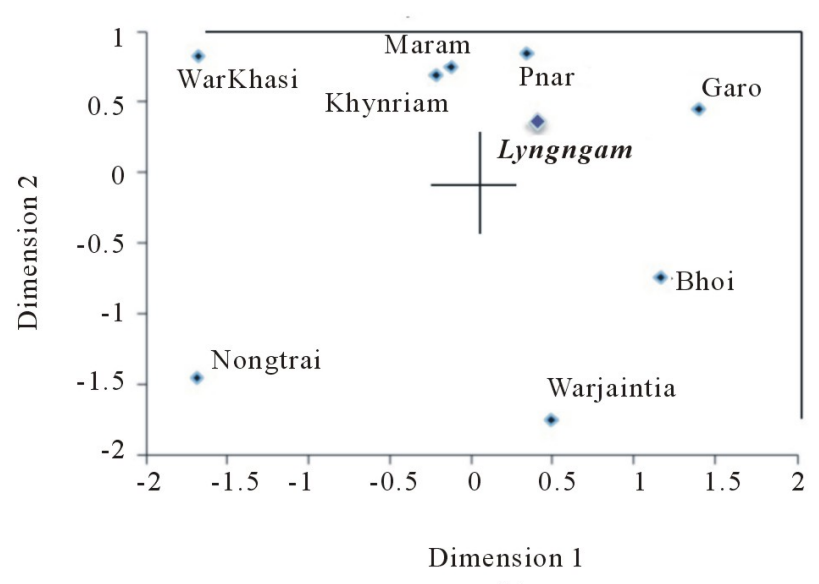

(b)

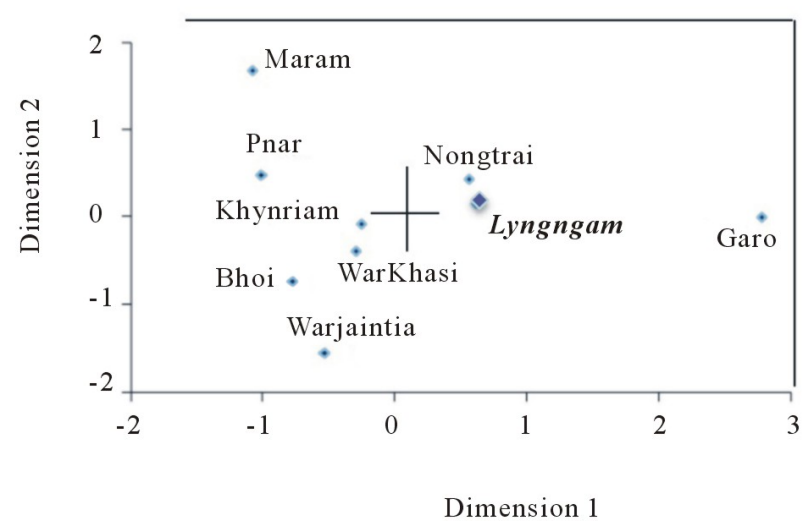

(d)

Figure 3.

Projection of Meghalaya tribal populations on the two-dimensional space based on the multi-dimensional scaling distances based on different sets of markers (For MDS, the stress value and $\mathrm{R}^{2}$ for Autosomal STR, Y-STR, HVS I and HVS II are $0.124 \& 0.94,0.214 \& 0.84,0.149 \& 0.93$ and 0.142 \& 0.92, respectively); (a) Autosomal STRS; (b) Y-STRS; (c) mtDNA HVRI; (d) mtDNA HVRII.

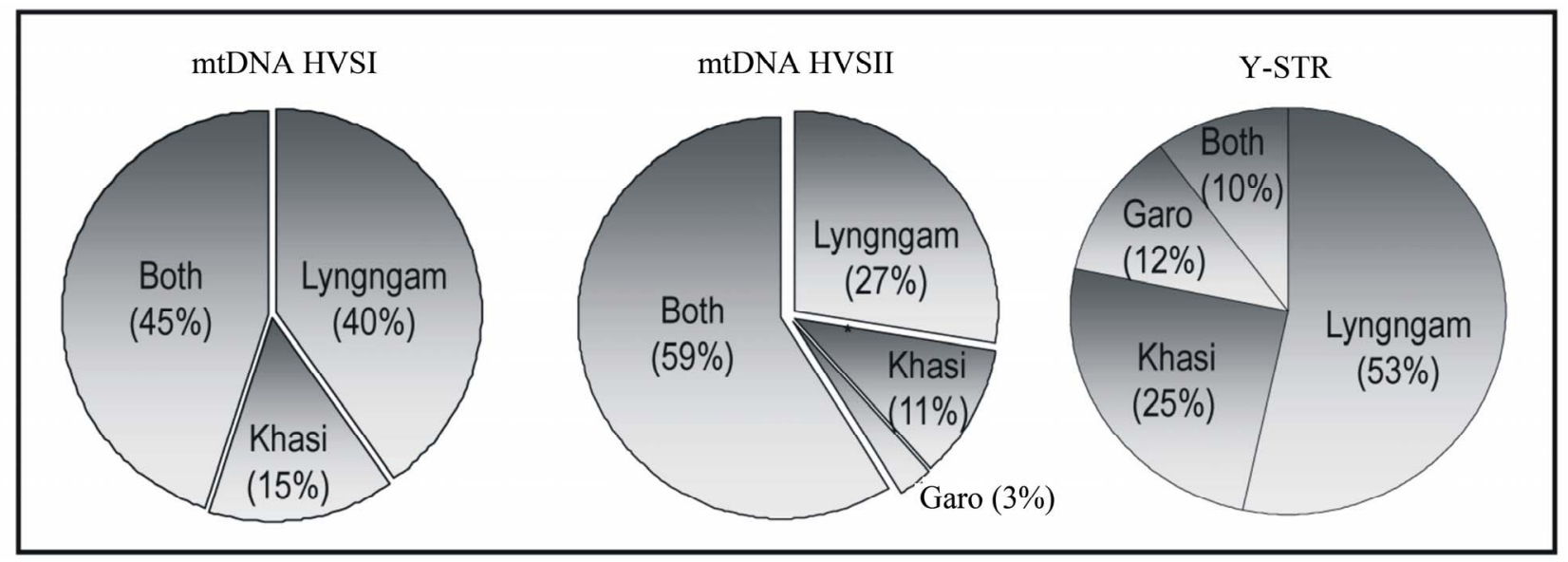

Figure 4.

Pattern of sharing of mtDNA and Y-STR haplotypes between Lyngngam individuals and putative parental populations, the Khasi and Garo.

the next highest contribution being from Pnar (12\%) and Garo $(11 \%)$.

On the other hand, the admixture proportions based on the allele frequency at the $6 \mathrm{Y}$-chromosome STR loci, contrary to the trend observed in Y-STR haplotype sharing, suggest that the Garo contribution (68\%) to Lyngngam outweighs that of the Khasi $(32 \%)$. Garo contribution is similarly high $(62 \%)$ in comparison to the neighbouring Khasi $(16 \%)$ and other Khasi 
groups $(22 \%)$. Further, when individual Khasi subtribes are considered as putative parental populations along with Garo, the contribution of Garo turns out to be much higher (79\%).

\section{Discussion}

Northeast region of India was considered as an important corridor for historic and prehistoric movement of populations into and out of the Indian subcontinent (Clark et al., 2000; Cordaux et al., 2003, 2004; Reddy et al., 2007) and provides complex population history characterized by multiple ethnic, linguistic and migration backgrounds. This has resulted in enormous cultural (Hussain, 1991; Sharma, 1966) and genetic diversity of this region as compared to the other regions of the country (Clark et al., 2000; Dutta et al., 2002; Cordaux et al., 2004; Langstieh et al., 2004b; Reddy et al., 2005). Populations of this region are predominantly of tribal origin, interspersed with some caste populations. Composed of East Asian and European ethnic elements, they speak languages of three major linguistic families-Tibeto-Burman, Indo-European and AustroAsiatic. Unlike in the rest of India, the tribal boundaries of these populations are somewhat permeable, creating possibilities for exchange of genes among them. The Lyngngam tribe of Meghalaya whose genetic origins are being investigated is in the midst of Austro-Asiatic Khasi and Tibeto-Burman Garo, the two tribal clusters that primarily inhabit this state. Having been affiliated to the same linguistic group, there is every indication that the Lyngngam might have originated from the common source as that of the Khasi populations. However, given its geographic position contiguous to Garo and only to a couple of Khasi subtribes, the Lyngngam has had little day-to-day interaction with the majority of the Khasi sub-tribes. In the above background, despite the lack of mobility of female lineages in this matrilocal society, the high proportions of Khasi specific autosomal and mtDNA lineages observed in the Lyngngam and vice versa reflect that the initial constitution/founding of female lineages of the Lyngngam and Khasi sub-populations probably would have been from a common source. As far as the individual Khasi populations are concerned, the Nongtrai neighbor seems the most probable candidate to have contributed predominantly to the Lyngngam female lineages as reflected by not only the high proportion of admixture $(\sim 53 \%)$ with refer-

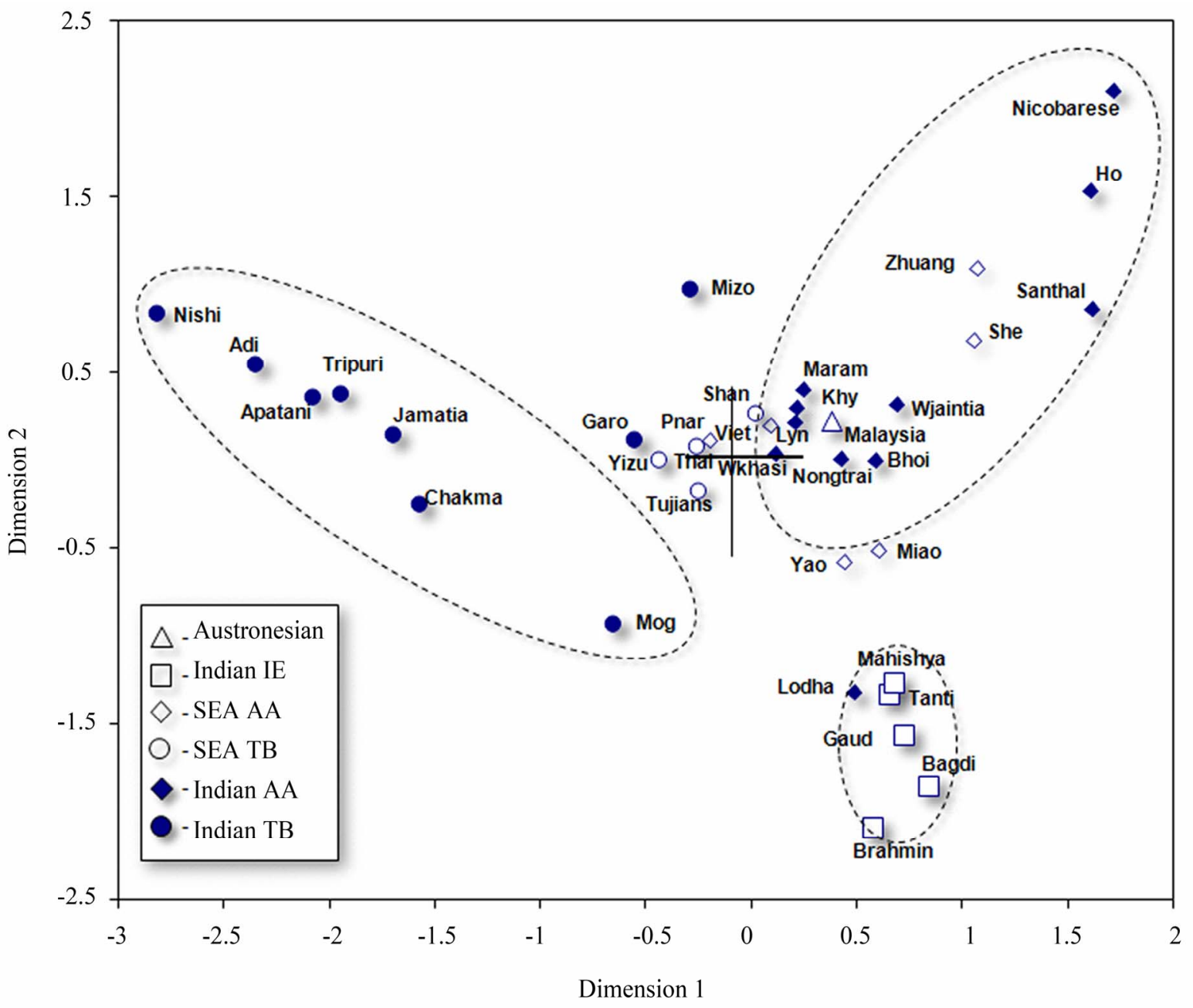

Figure 5.

Plot on the first two dimensions derived from the multi-dimensional scaling of the pairwise $\mathrm{F}_{\mathrm{ST}}$ distances of the populations based on Y-haplogroups (for comparative data, refer Reddy et al., 2007). SEA = Southeast Asian; AA = Austro-Asiatic; IE = Indo-European; TB = Tibeto-Burman; Khy = Khynriam; Lyn = Lyngngam; Wkhasi = War Khasi; Viet = Vietnamese (adapted from Reddy et al., 2007). 


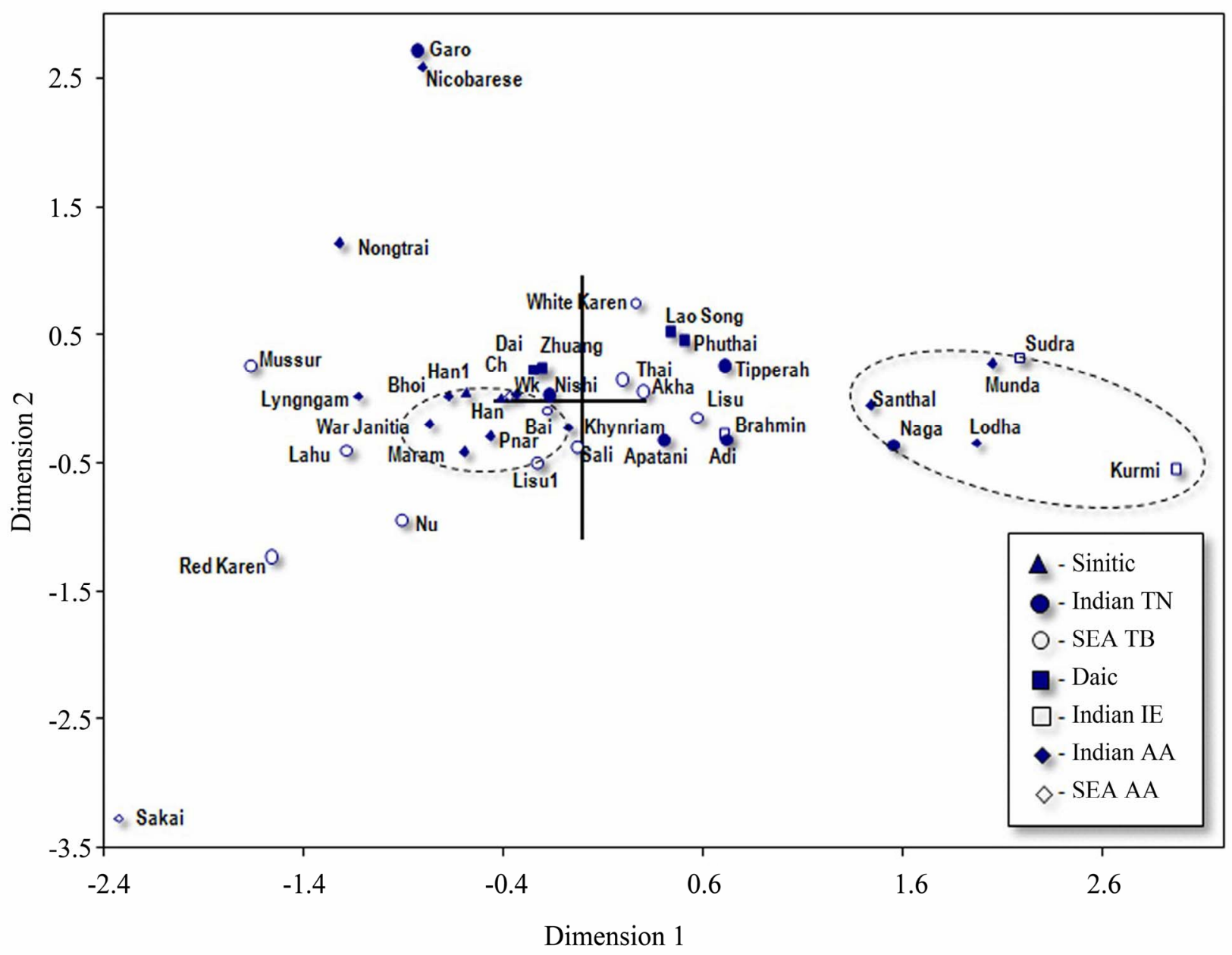

Figure 6.

Plot on the first two-dimensions derived from the multidimensional scaling of the pairwise $\mathrm{F}_{\mathrm{ST}}$ distances of the populations based on mtDNA haplogroups (for comparative data, refer Reddy et al., 2007). SEA = Southeast Asian; AA = Austro-Asiatic; IE = Indo-European; TB = Tibeto-Burman; $\mathrm{Wk}=$ WarKhasi; $\mathrm{Ch}=$ Chong (adapted from Reddy et al., 2007).

ence to mtDNA HVS sequences but also the high proportion of common maternal clans found among the Nongtrai and Lyngngam (Langstieh \& Reddy, 2004). This is reflected partly in the high mantel correlation between geographic and genetic distance matrices based on mtDNA sequences as well as in the relative proximity of the Lyngngam to the Nongtrai in the MDS plot based on mtDNA distances (Figure 3).

To sum up, the foregoing analyses of the ethnohistoric, linguistic and demographic information in conjunction with the molecular genetic evidence trace Khasi (more particularly the Nongtrai subtribe of Khasi) as the most probable parental source of the Lyngngam, which is consistent with the first of the four notions concerning the origin of this tribe as outlined in the introduction. Nevertheless, it is necessary to discount the possibility of Lyngngam origin from the sources outside Meghalaya/India, particularly from the populations of Southeast Asia, where from many Tibeto-Burman populations were known to have migrated to Northeast India, before any rational conclusion on their origin can be drawn. A strong support for Khasi origin of the Lyngngam can be drawn from Reddy et al. (2007) who performed multidimensional scaling analysis of the $F_{\mathrm{ST}}$ distances based on mtDNA and Y-chromosome haplogroup frequency data of the Austro-Asiatic and non-Austro-Asiatic populations from the South and Southeast Asia, including the 7 Khasi subtribes, Lyngngam and Garo of the present study. The two-dimensional plots representing the populations in the multivariate space are reproduced here for Y-chromosome (Figure 5) and mtDNA (Figure 6). The position of Lyngngam in both the plots is relatively more proximate to the Austro-Asiatic Khasi tribes of Meghalaya when compared to the Garo as well as to other South Asian and Southeast Asian populations, Austro-Asiatic or non Austro-Asiatic, ruling out the possibility of their origin from outside Meghalaya and/or outside the Austro-Asiatic Khasi. There is nothing in the results that goes against concluding Khasi (particularly the Nongtrai) origin of the Lyngngam tribe despite limited statistical power of the study with small number of genetic loci employed.

\section{REFERENCES}

Ahmed, T. J., Sengupta, S., \& Ghosh, A. K. (1997). A genetic study on the Lyngàm of Meghalaya. Journal of Human Ecology, 8, 473-475.

Andrews, R. N., Kubacka, I., Chinnery, P. F., Lightowlers, R. N., Turnbull, D. M., \& Howell, N. (1999). Reanalysis and revision of the Cambridge reference sequence for human mitochondrial DNA. $\mathrm{Na}$ - 
ture Genetics, 23, 147. doi:10.1038/7727

Applied Biosystems (2001). PCR protocols for AmpFeSTR profiler plus. $P E$ applied biosystems human identification group. Foster City, CA: Applied Biosystems.

Bareh, H. (1967). The history and culture of the Khasi people. Guahati: Spectrum Publications.

Barrett, D. (1982). World christian encyclopedia. New York.

Bertorelle, G., \& Excoffier, L. (1998). Inferring admixture proportions from molecular data. Molecular Biology and Evolution, 15, 12981311. doi:10.1093/oxfordjournals.molbev.a025858

Bhattacharjee, J. B. (1978). The Garos and the English. New Delhi: Radiant Publishers.

Butler, J. M., Schoske, R., Vallone, P. M., Kline, M. C., Redd, A. J. et al. (2002). A novel multiplex for simultaneous amplification of 20 Y-chromosome STR markers. Forensic Science International, 129, 10-24. doi:10.1016/S0379-0738(02)00195-0

Cann, R. L., Stoneking, M., \& Wilson, A. C. (1987). Mitochondrial DNA and human evolution. Nature, 325, 31-36. doi: $10.1038 / 325031 \mathrm{a} 0$

Chakraborty, R. (1986). Gene admixture in human populations: Models and predictions. Yearbook of Physical Anthropology 29, 1-43. doi:10.1002/ajpa.1330290502

Chu, J. Y., Huang, W., Kuang, S. Q., Wang, J. M., Xu, J. J., Chu, Z. T., Yang, Z. Q., Lin, K. Q., Li, P., Wu, M., Geng, Z. C., Tan, C. C., Du, R. F., \& Jin, L. (1998). Genetic relationship of populations in China. Proceedings of the National Academy of Sciences, 95, 11763-11768. doi:10.1073/pnas.95.20.11763

Clark, V. J., Sivendran, S., Saha, N., Bentley, G. R., Aunger, R., Sirajuddin, S. M., \& Stoneking, M. (2000). The 9-bp deletion between the mitochondrial Lysine tRNAand COII genes in tribal populations of India. Human Biology, 72, 273-285.

Cordaux, R., Saha, N., Bentley, G. R., Aunger, R., Sirajuddin, S. M., \& Stoneking, M. (2003). Mitochondrial DNA analysis reveals diverse histories of tribal populations from India. European Journal of Human Genetics, 11, 253-264. doi:10.1038/sj.ejhg.5200949

Cordaux, R., Weiss, G., Saha, N., \& Stoneking, M. (2003). The Northeast Indian passageway: A barrier or corridor for human migrations? Molecular Biology and Evolution, 21, 1525-1533. doi:10.1093/molbev/msh151

Crawford, M. H., Reddy, B. M., Martinez-Laso, J., Mack, S., Erlich, H. (2001). Genetic variation among the Golla pastoral caste subdivisions of Andhra Pradesh, India: HLA system. Human Immunology, 62, 1031-1041. doi:10.1016/S0198-8859(01)00312-3

Diffloth, G. (2005). The contribution of linguistic palaeontology to the homeland of Austro-Asiatic. In L. Sagart, R. Blench, \& A. Sanchez-Mazas (Eds.), The Peopling of East Asia: Putting Together Archaeology, Linguistics and Genetics (pp. 77-81). London: Routledge Curzon.

Dipierri, J. E., Alfaro, E., Martínez-Marignac, V. L., Bailliet, G., Bravi, C. M., Cejas, S., \& Bianchi, N. (1998). Paternal directional mating in two Amerindian subpopulations located at different altitudes in northwestern Argentina. Human Biology, 70, 1001-1010.

Dupanloup, I., \& Bertorelle, G. (2000). Computing admixture coefficients from molecular data. http://cmpg.unibe.ch/software/admix/

Dutta, R., Reddy, B. M., Chattopadhyay, P., Kashyap, V. K., Sun, G., \& Deka, R. (2002). Patterns of genetic diversity at the 9 forensically approved STR loci among the Indian populations. Human Biology, 74, 33-49. doi:10.1353/hub.2002.0002

Ehrenfels, U. R. (1955). Three matrilineal groups of Assam. American Anthropologist, 57, 306-321. doi:10.1525/aa.1955.57.2.02a00080

Grierson, G. A. (1928). The Mon-Khmer family. In G. A. Grierson, (Ed.) Languages of North Eastern India-A Survey (pp. 1-57). New Delhi: Gian Publishing House.

Gurdon, P. R. T. (1907). The Khasis. New Delhi: Low Price Publication.

Hussain, Z. (1991). Who are the pre-historic dwellers of the Meghalaya plateau? In J. P. Singh, \& G. Sengupta, (Eds.), Archaeology of North East India (pp. 74-85). New Delhi: Vikas Publishing House Pvt. Ltd. Jorde, L. B., Rodgers, A. R., Bamshad, M., Watkins, W. S., Krakowiak, P., Sung, S., Kere, J., \& Harpending, H. C. (1997). Microsatellite diversity and the demographic history of modern humans. Proceedings of the National Academy of Sciences, 94, 3100-3103. doi:10.1073/pnas.94.7.3100

Karve, I., \& Dandekar, V. M. (1951). Anthropometric measurements of Maharashtra. Deccan College Monograph Series 8.

Karve, I., \& Malhotra, K. C. (1968). Biological comparison of eightendogamous groups of the same rank. Current Anthropology, 9, 109-124. doi:10.1086/200976

Karve, I. (1961). Hindu society, an interpretation. Poona: Deccan College.

Kittles, R. A., Bergen, A. W., Urbanek, M., Virkkunen, M., Linnoila, M., Goldman, D., \& Long, J. (1999). Autosomal, mitochondrial and Y chromosome DNA variation in Finland: Evidence for a male-specific bottleneck. American Journal of Physical Anthropology, 108, 381-399. doi:10.1002/(SICI)1096-8644(199904)108:4<381::AID-AJPA1>3.0. $\mathrm{CO} ; 2-5$

Kivisild, T., Bamshad, M. J., Kaldma, K., Metspalu, M., Metspalu, E., Reidla, M., Laos, S., Parik, J., Watkins, W. S., Dixon, M. E., Papiha, S. S., Mastana, S. S., Mir, M. R., Ferak, V., \& Villems, R. (1999). Deep common ancestry of Indian and Western Eurasian mitochondrial DNA lineages. Current Biology, 9, 1331-1334.

doi:10.1016/S0960-9822(00)80057-3

Kivisild, T., Rootsi, S., Metspalu, M., Mastana, S., Kaldma, K., Parik, J., Metspalu, E., Adojaan M., Tolk, H. V., Stepanov, V., Golge, M., Usanga, E., Papiha, S. S., Cinnioglu, C., King, R., Cavalli-Sforza, L., Underhill, P. A., \& Villems, R. (2003). The genetic heritage of the earliest settlers persists both in Indian tribal and caste populations. American Journal of Human Genetics, 72, 313-339. doi: $10.1086 / 346068$

Kivisild, T., Tolk, H. V., Parik, J., Wang, Y., Papiha, S. S., Bandelt, H.-J., \& Villems, R. (2002). The emerging limbs and twigs of the East Asian mtDNA tree. Molecular Biology Evolution, 19, $1737-$ 1751.doi:10.1093/oxfordjournals.molbev.a003996

Kong, Q. P., Yao, Y. G., Sun, C., Bandelt, H. J., Zhu, C. L. et al. (2003). Phylogeny of East Asian mitochondrial DNA lineages inferred from complete sequences. American Journal of Human Genetics, 73, 671676. doi:10.1086/377718

Kumar, V., Basu, D., \& Reddy, B. M. (2004). Genetic heterogeneity in northeastern India: Reflection of Tribe-Caste continuum in the genetic structure. American Journal Human Biology, 16, 334-345. doi:10.1002/ajhb.20027

Kumar, V., Reddy, A. N. S., Babu, J. P., Rao, T. N., Langstieh, B. T., Thangaraj, K., Reddy, A. G., Singh, L., \& Reddy, B. M. (2007). Y-chromosome evidence suggests a common paternal heritage of Austro-Asiatic populations. BMC Evolutionary Biology, 7, 47. doi:10.1186/1471-2148-7-47

Langstieh, B. T. (2003). Ethnic origin and population structure of the Lyngngam of Meghalaya, India. Ph.D. Thesis, Calcutta: Calcutta University.

Langstieh, B. T., \& Reddy, B. M. (2004a). Ethno-historic and linguistic background of the Lyngngam and its demographic structure. Journal of North Eastern Hill University, 2, 15-42.

Langstieh, B. T., Reddy, B. M., Thangaraj, K., Kumar, V., \& Singh, L. (2004b). Genetic diversity and relationships among the tribes of Meghalaya compared to other Indian and Continental populations. Human Biology, 76, 569-90. doi:10.1353/hub.2004.0057

Langstieh, B. T., \& Reddy, B. M. (1999). The origin and ethnic position of Lyngngam among the tribes of Meghalaya: An exploratory study. Journal of Indian Anthropological Society, 34, 265-275.

Malhotra, K. C. (1978). Founder effect, gene drift and natural selection among four nomadic Mendelian isolates. In R. J. Meier et al. (Eds.), Evolutionary models and studies in human diversity (pp. 279-314). 
The Hague: Mouton. doi:10.1515/9783110800043.315

Malhotra, K. C. (1979). Excommunication as a process leading to the formation of new groups. The Eastern Anthropologist, 32, 49-53.

Malhotra, K. C. (1984). Population structure among the Dhangar castecluster of Maharashtra, India. In J. R. Lukacs (Ed.), The People of South Asia (pp. 295-324). New York: Plenum Press.

Malhotra, K. C., \& Vasulu, T. S. (1993). Structure of human populations in India. In P. P. Majumder (Ed.), Human Population Genetics (pp. 207-233). New York: Plenum Press.

doi:10.1007/978-1-4615-2970-5_15

Mathur, P. R. (1979). The Khasi of Meghalaya. New Delhi: Cosmo.

Mitchell, R. J., Reddy, B. M., Campo, D., Infantino, T., Kaps, M., \& Crawford, M. H. (2006). Genetic diversity within a caste population of India as measured by $\mathrm{Y}$ chromosome haplogroups and haplotypes: sub-castes of the Golla of Andhra Pradesh. American Journal of Physical Anthropology, 130, 385-393. doi:10.1002/ajpa.20329

Nei, M., Tajima, F., \& Tateno, Y. (1983). Accuracy of estimated phylogenetic trees from molecular data. Journal of Molecular Evolution, 19, 153-170. doi:10.1007/BF02300753

Nongsiang, E. D. (1994). Various forms of festivals and ceremonies of the Lyngams. In K. R. Marak, \& R. Wankhar (Eds.), Festivals and Ceremonies in Meghalaya (pp 120-123). Shillong: Department of Art and Culture, Government of Meghalaya.

Playfair, A. (1909). The Garos. Gauhati: United Publishers, Reprint 1975.

Reddy, B. M. (1983). Temporal trends in marriage distance and village endogamy among the migrant groups of fishermen of coastal Orissa. Collagium Anthropologicum, 7, 125-135.

Reddy, B. M. (1984). Demographic structure of the migrant groups of fishermen of Puri coast, India. Journal of Biosocial Sciences, 16, 385-398. doi:10.1017/S0021932000015200

Reddy, B. M. (2010). Population structure and genetic perspectives on the Indian fishermen. In M. K. Bhasin, \& C. Sussane (Eds.), Anthropology Today: Trends and Scope of Human Biology. Anthropologist, 6, 165-181.

Reddy, B. M., Chopra, V. P., Rodewaldt, A., Dey. B., Veerraju, P., \& Rao, T. V. (1995). Genetic affinities between migrant and parental populations of fishermen on the east coast of India. American Journal of Human Biology, 7, 51-63. doi:10.1002/ajhb.1310070108

Reddy, B. M., \& Chopra, V. P. (1999). Biological affinities between the parental and migrant populations of fishermen of the east coast of India. Human Biology, 71, 803-822.

Reddy, B. M., Sun, G., Javier, R. L., Crawford, M. H., Hemam, N. S., \& Deka, R. (2001a). Genomic diversity at the 13 STR loci among the 7 subcastes of the substructured Golla population of southern Andhra Pradesh, India . Human Biology, 73, 175-190. doi:10.1353/hub.2001.0025

Reddy, B. M., Demarchi, D. A., \& Malhotra, K. C. (2001b). Patterns of variation in a caste-cluster of Dhangars of Maharashtra, India. Collagium Antropologicum, 25, 425-442.

Reddy, B. M., Pfeiffer, A., Crawford, M. H., \& Langstieh, B. T. (2001). Population substructure and patterns of quantitative variation among the Gollas of southern Andhra Pradesh, India. Human Biology, 73, 291-306. doi:10.1353/hub.2001.0026

Reddy, B. M., Naidu, V. M., Madhavi, V. K., Thangaraj, K., Kumar, V., Langstieh, B. T., Venkatramana, P. V., Reddy, A. G., \& Singh, L. (2005). Microsatellite diversity in Andhra Pradesh, India: Geneticstratification versus social stratification. Human Biology, 77, 803823. doi: $10.1353 /$ hub. 2006.0018
Reddy, B. M., Langstieh, B. T., Kumar, V., Nagaraja, T., Aruna, M., Thangaraj, K., Reddy, A. N. S., Reddy, A. G., \& Singh, L. (2007). Austro-asiatic tribes of northeast India provide missing genetic link between south and Southeast Asia. PLoS One, 2, e1141

Reddy, B. M., Tripathy, V., Kumar, V., \& Nirmala , A. (2010). Molecular genetic perspectives on the Indian social structure. American Journal of Human Biology, 22, 410-417. doi:10.1002/ajhb.20983

Relethford, J. H. (1993). MANTEL for Windows version 2.0.

Rodborne, T. (1977). U Khasi. Shillong, Meghalaya, Shillong: Mrs. H. Rodborne.

Sambrook, J., Fritsch, E. F., \& Maniatis, T. (1989). Molecular cloning. A laboratory manual (2nd ed.). New York: Cold Spring Harbor Laboratory Press.

Sangma, M. S. (1981). History and Culture of the Garos. New Delhi: Cosmo Publishing.

Schneider, S., Roessli, D., \& Excoffier, L. (2000). Arlequin ver. 2.000: A software for population genetics data analysis. Switzerland: Genetics and Biometry Laboratory, University of Geneva.

Sharma, T. C. (1966). Researches on the prehistoric archaeology of Assam. Journal of the Assam Scientific Society, 9, 1-11.

Su, B., Xiao, J., Underhill, P., Deka, R., Zhang, W., Akey, J., Huang, W., Shen, D., Lu, D., Luo, J., Chu, J., Tan, J., Shen, P., Davis, R., Cavalli-Sforza, L., Chakraborty, R., Xiong, M., Du, R., Oefner, P., Chen, Z., \& Jin, L. (1999). Y-chromosome evidence for a northward migration of modern humans into eastern Asia during the last ice age. American Journal Human Genetics, 65, 1718-1724. doi: $10.1086 / 302680$

Swadesh, M. (1950). Salish internal relationships. International Journal American Linguistics, 16, 157-167. doi:10.1086/464084

Swadesh, M. (1951). Diffusional accumulation and archaic residue as historical explanations. Southern Journal of Anthropology, 7, 1-21.

Swadesh, M. (1972). The origin and diversification of language. London: Routledge \& Kagen Paul.

Thapa, R., Sengupta, S., \& Ghosh, A. K. (1998). Dermatoglyphics of the lyngngàm of meghalaya. Indian Journal of Human Ecology, 9 , 629-631.

Underhill, P. A., Shen, P., Lin, A. A., Jin, L., Passarino, G., Yang, W. H., Kauffman, E., Bonné-Tamir, B., Bertrandpetit, J., Francalacci, P., Ibrahim, M., Jenkins, T., Kidd, J. R., Mehdi, S. Q., Seielstad, M. T., Wells, R. S., Piazza, A., Davis, R. W., Feldman, M. W., CavalliSforza, L. L., \& Oefner, P. J. (2000). Y chromosome sequence variation and the history of human populations. Nature Genetics, 26, 358361. doi: $10.1038 / 81685$

Wells, R. S., Yuldasheva, N., Ruzibakiev, R., Underhill, P. A., Evseeva, I., Blue-Smith, J., Jin, L., Su, B., Picchappan, R., Shanmugalakshmi, S., Balakrishnan, K., Read, M., Pearson, N. M., Zerjal, T., Webster, M. T., Zholoshvili, I., Jamarjashvili, E., Gambarov, S., Nikbin, B., Dostiev, A., Aknazarov, O., Zalloua, P., Tsoy, I., Kitaev, M., Mirrakhimov, M., Chariev, A., \& Bodmer, W. F. (2001). The Eurasian heartland: A continental perspective on Y-chromosome diversity. Proceedings of the National Academy of Sciences, 98, 10244-10249. doi:10.1073/pnas.171305098

Williams, R. C., Knowler, W. C., Pettitt, D. J., Long, J. C., Rokala, D. A., Polesky, H. F., Hackenberg, R. A., Steinberg, A. G., \& Bennett, P. H. (1992). The magnitude and origin of European-American admixture in the Gila River Indian community of Arizona: A union of genetics and demography. American Journal of Human Genetics, 51, 101-110. 
B. T. LANGSTIEH ET AL.

\section{Appendix}

Table S1.

Sharing pattern of the Lyngam Y-haplotypes with the neighbouring Khasi and Garo.

\begin{tabular}{|c|c|c|c|c|c|c|c|c|c|c|c|c|c|c|c|c|}
\hline & DYS & DYS & DYS & DYS & DYS & DYS & & & & & & & & & & \\
\hline Hap. No. & 19 & $389 \mathrm{I}$ & $389 \mathrm{II}$ & 390 & 391 & 393 & Lyng & Garo & Nong & Mara & Khyn & Pnar & Bhoi & WarK & WarJ & Total \\
\hline \multicolumn{17}{|c|}{ Unique to Lyngam } \\
\hline Hap1 & 14 & 11 & 27 & 9 & 10 & 11 & 1 & & & & & & & & & 1 \\
\hline Hap2 & 16 & 9 & 26 & 11 & 10 & 12 & 2 & & & & & & & & & 2 \\
\hline Hap3 & 15 & 11 & 27 & 9 & 10 & 13 & 1 & & & & & & & & & 1 \\
\hline Hap4 & 14 & 9 & 25 & 10 & 10 & 13 & 1 & & & & & & & & & 1 \\
\hline Hap5 & 14 & 10 & 25 & 10 & 10 & 13 & 1 & & & & & & & & & 1 \\
\hline Hap7 & 14 & 9 & 27 & 9 & 10 & 13 & 1 & & & & & & & & & 1 \\
\hline Hap8 & 15 & 8 & 29 & 11 & 10 & 13 & 1 & & & & & & & & & 1 \\
\hline Hap9 & 15 & 8 & 27 & 9 & 10 & 12 & 1 & & & & & & & & & 1 \\
\hline Hap10 & 12 & 9 & 26 & 9 & 10 & 12 & 1 & & & & & & & & & 1 \\
\hline Hap11 & 15 & 9 & 26 & 11 & 10 & 13 & 1 & & & & & & & & & 1 \\
\hline Hap12 & 15 & 9 & 28 & 11 & 10 & 13 & 1 & & & & & & & & & 1 \\
\hline Hap13 & 15 & 14 & 28 & 10 & 10 & 12 & 1 & & & & & & & & & 1 \\
\hline Hap15 & 13 & 9 & 26 & 9 & 10 & 16 & 1 & & & & & & & & & 1 \\
\hline Hap16 & 16 & 9 & 27 & 10 & 11 & 13 & 1 & & & & & & & & & 1 \\
\hline Hap17 & 15 & 9 & 27 & 10 & 11 & 13 & 1 & & & & & & & & & 1 \\
\hline Hap18 & 15 & 8 & 27 & 10 & 10 & 13 & 1 & & & & & & & & & 1 \\
\hline Hap19 & 17 & 10 & 27 & 10 & 10 & 12 & 1 & & & & & & & & & 1 \\
\hline Hap20 & 15 & 10 & 26 & 11 & 11 & 12 & 1 & & & & & & & & & 1 \\
\hline Hap21 & 16 & 10 & 28 & 10 & 10 & 13 & 1 & & & & & & & & & 1 \\
\hline Hap22 & 15 & 10 & 27 & 9 & 11 & 16 & 1 & & & & & & & & & 1 \\
\hline Hap23 & 16 & 9 & 26 & 11 & 10 & 13 & 1 & & & & & & & & & 1 \\
\hline Hap24 & 16 & 10 & 26 & 11 & 10 & 14 & 1 & & & & & & & & & 1 \\
\hline Hap25 & 15 & 10 & 27 & 9 & 10 & 14 & 1 & & & & & & & & & 1 \\
\hline Нар26 & 17 & 10 & 27 & 10 & 10 & 13 & 1 & & & & & & & & & 1 \\
\hline
\end{tabular}




\begin{tabular}{|c|c|c|c|c|c|c|c|c|c|c|c|c|c|c|c|c|}
\hline Hap27 & 15 & 10 & 24 & 12 & 10 & 13 & 1 & & & & & & & & & 1 \\
\hline Hap28 & 15 & 11 & 28 & 8 & 11 & 11 & 1 & & & & & & & & & 1 \\
\hline Нар29 & 15 & 11 & 28 & 8 & 10 & 12 & 1 & & & & & & & & & 1 \\
\hline Hap30 & 14 & 9 & 26 & 10 & 11 & 11 & 1 & & & & & & & & & 1 \\
\hline \multicolumn{17}{|c|}{ Shared with either Khasi or Garo } \\
\hline Hap31 & 15 & 9 & 27 & 10 & 10 & 12 & 1 & 3 & & & & & & & & 4 \\
\hline Hap32 & 14 & 9 & 25 & 9 & 10 & 11 & 1 & 2 & & & & & & & & 3 \\
\hline Hap33 & 15 & 9 & 26 & 9 & 11 & 12 & 1 & 1 & & & & & & & & 2 \\
\hline Hap34 & 15 & 9 & 26 & 10 & 10 & 11 & 1 & 1 & & & & & & & & 2 \\
\hline Hap35 & 15 & 10 & 29 & 11 & 10 & 12 & 1 & 1 & & & & & & & & 2 \\
\hline Hap36 & 13 & 10 & 27 & 10 & 10 & 12 & 1 & 1 & & & & & & & & 2 \\
\hline Hap37 & 17 & 9 & 26 & 10 & 10 & 11 & 1 & 1 & & & & & & & 1 & 3 \\
\hline Hap38 & 15 & 10 & 27 & 9 & 10 & 13 & 1 & & & & 1 & & & & & 2 \\
\hline Hap39 & 15 & 9 & 27 & 9 & 11 & 12 & 1 & & & & & & 1 & & & 2 \\
\hline Hap40 & 15 & 9 & 27 & 9 & 10 & 11 & 1 & & & & 1 & & & & & 2 \\
\hline Hap41 & 14 & 9 & 26 & 9 & 10 & 13 & 1 & & & & 1 & & & & & 2 \\
\hline Hap42 & 15 & 11 & 27 & 11 & 11 & 13 & 1 & & & & & & 1 & & & 2 \\
\hline Hap43 & 15 & 10 & 26 & 11 & 11 & 13 & 2 & & & 1 & & & & 1 & & 4 \\
\hline Hap44 & 15 & 11 & 29 & 11 & 10 & 12 & 1 & & & & 1 & & & & & 2 \\
\hline Hap45 & 16 & 11 & 28 & 11 & 11 & 12 & 1 & & & 2 & & & & & & 3 \\
\hline Hap46 & 15 & 10 & 27 & 9 & 11 & 12 & 1 & & & & 1 & & 1 & & & 3 \\
\hline Hap47 & 15 & 11 & 26 & 11 & 11 & 13 & 1 & & & & & & & 1 & & 2 \\
\hline Hap48 & 15 & 9 & 26 & 11 & 10 & 11 & 1 & & & & 1 & 2 & & & & 4 \\
\hline Hap49 & 16 & 10 & 27 & 11 & 10 & 12 & 1 & & & 1 & & & & & 1 & 3 \\
\hline Hap50 & 16 & 10 & 26 & 11 & 10 & 12 & 1 & & & & & 1 & & & & 2 \\
\hline Hap51 & 15 & 10 & 26 & 9 & 11 & 13 & 1 & & 3 & & & & & & & 4 \\
\hline \multicolumn{17}{|c|}{ Shared with both Khasi and Garo } \\
\hline Hap52 & 15 & 10 & 27 & 10 & 10 & 13 & 1 & 2 & & & 1 & & 1 & & & 5 \\
\hline Hap53 & 15 & 9 & 27 & 10 & 10 & 13 & 3 & 1 & & & & 1 & & & & 5 \\
\hline Hap54 & 15 & 9 & 26 & 9 & 10 & 11 & 2 & 3 & 1 & & & & 1 & & & 7 \\
\hline
\end{tabular}


B. T. LANGSTIEH ET AL.

Table S2.

Distribution and frequency of maternally shared HVR I haplotypes of Lyngngam with Garo and Khasi populations.

\begin{tabular}{|c|c|c|c|c|c|c|c|c|c|c|}
\hline Haplotype & Lyngngam & Garo & Nongtrai & Maram & Khynriam & Pnar & Bhoi & WarKhasi & WarJaintia & \\
\hline & $\mathbf{n}=\mathbf{8 2}$ & $\mathbf{n}=\mathbf{8 7}$ & $\mathbf{n}=\mathbf{3 0}$ & $n=72$ & $\mathbf{n}=95$ & $n=69$ & $\mathrm{n}=\mathbf{3 4}$ & $\mathbf{n}=\mathbf{3 1}$ & $\mathbf{n}=\mathbf{2 2}$ & \\
\hline \multicolumn{3}{|c|}{ Unique to Lyngngam } & & & & & & & & Total \\
\hline 1 & 1 & 0 & 0 & 0 & 0 & 0 & 0 & 0 & 0 & 1 \\
\hline 2 & 1 & 0 & 0 & 0 & 0 & 0 & 0 & 0 & 0 & 1 \\
\hline 3 & 1 & 0 & 0 & 0 & 0 & 0 & 0 & 0 & 0 & 1 \\
\hline 4 & 1 & 0 & 0 & 0 & 0 & 0 & 0 & 0 & 0 & 1 \\
\hline 5 & 1 & 0 & 0 & 0 & 0 & 0 & 0 & 0 & 0 & 1 \\
\hline 6 & 1 & 0 & 0 & 0 & 0 & 0 & 0 & 0 & 0 & 1 \\
\hline 7 & 1 & 0 & 0 & 0 & 0 & 0 & 0 & 0 & 0 & 1 \\
\hline 8 & 1 & 0 & 0 & 0 & 0 & 0 & 0 & 0 & 0 & 1 \\
\hline 10 & 5 & 0 & 0 & 0 & 0 & 0 & 0 & 0 & 0 & 5 \\
\hline 11 & 1 & 0 & 0 & 0 & 0 & 0 & 0 & 0 & 0 & 1 \\
\hline 12 & 1 & 0 & 0 & 0 & 0 & 0 & 0 & 0 & 0 & 1 \\
\hline 13 & 1 & 0 & 0 & 0 & 0 & 0 & 0 & 0 & 0 & 1 \\
\hline 14 & 1 & 0 & 0 & 0 & 0 & 0 & 0 & 0 & 0 & 1 \\
\hline 15 & 2 & 0 & 0 & 0 & 0 & 0 & 0 & 0 & 0 & 2 \\
\hline 16 & 1 & 0 & 0 & 0 & 0 & 0 & 0 & 0 & 0 & 1 \\
\hline 17 & 1 & 0 & 0 & 0 & 0 & 0 & 0 & 0 & 0 & 1 \\
\hline 18 & 1 & 0 & 0 & 0 & 0 & 0 & 0 & 0 & 0 & 1 \\
\hline 19 & 1 & 0 & 0 & 0 & 0 & 0 & 0 & 0 & 0 & 1 \\
\hline 22 & 1 & 0 & 0 & 0 & 0 & 0 & 0 & 0 & 0 & 1 \\
\hline 23 & 2 & 0 & 0 & 0 & 0 & 0 & 0 & 0 & 0 & 2 \\
\hline 24 & 1 & 0 & 0 & 0 & 0 & 0 & 0 & 0 & 0 & 1 \\
\hline 25 & 1 & 0 & 0 & 0 & 0 & 0 & 0 & 0 & 0 & 1 \\
\hline 26 & 1 & 0 & 0 & 0 & 0 & 0 & 0 & 0 & 0 & 1 \\
\hline 27 & 1 & 0 & 0 & 0 & 0 & 0 & 0 & 0 & 0 & 1 \\
\hline \multicolumn{11}{|c|}{ Shared with only Khasi } \\
\hline 28 & 1 & 0 & 0 & 0 & 5 & 0 & 0 & 0 & 1 & 7 \\
\hline 29 & 5 & 0 & 1 & 2 & 8 & 5 & 1 & 4 & 2 & 28 \\
\hline 30 & 2 & 0 & 0 & 1 & 0 & 0 & 0 & 0 & 0 & 3 \\
\hline 31 & 1 & 0 & 1 & 0 & 0 & 0 & 0 & 0 & 0 & 2 \\
\hline 32 & 1 & 0 & 1 & 1 & 0 & 0 & 0 & 0 & 0 & 3 \\
\hline 33 & 1 & 0 & 0 & 12 & 6 & 3 & 0 & 1 & 0 & 23 \\
\hline 34 & 1 & 0 & 0 & 0 & 0 & 0 & 0 & 2 & 0 & 3 \\
\hline \multicolumn{11}{|c|}{ Shared with both Khasi and Garo } \\
\hline 35 & 3 & 10 & 1 & 0 & 1 & 1 & 0 & 0 & 0 & 16 \\
\hline 36 & 9 & 42 & 3 & 0 & 0 & 0 & 0 & 1 & 0 & 55 \\
\hline 37 & 14 & 1 & 4 & 3 & 2 & 4 & 1 & 1 & 0 & 30 \\
\hline 38 & 3 & 1 & 3 & 5 & 0 & 2 & 0 & 0 & 0 & 14 \\
\hline 39 & 4 & 2 & 1 & 0 & 0 & 0 & 0 & 0 & 0 & 7 \\
\hline 40 & 4 & 1 & 0 & 1 & 0 & 0 & 1 & 0 & 0 & 7 \\
\hline
\end{tabular}


B. T. LANGSTIEH ET AL.

Table S3.

Distribution and frequency of maternally shared HVR II haplotypes of Lyngngam with Garo and Khasi populations.

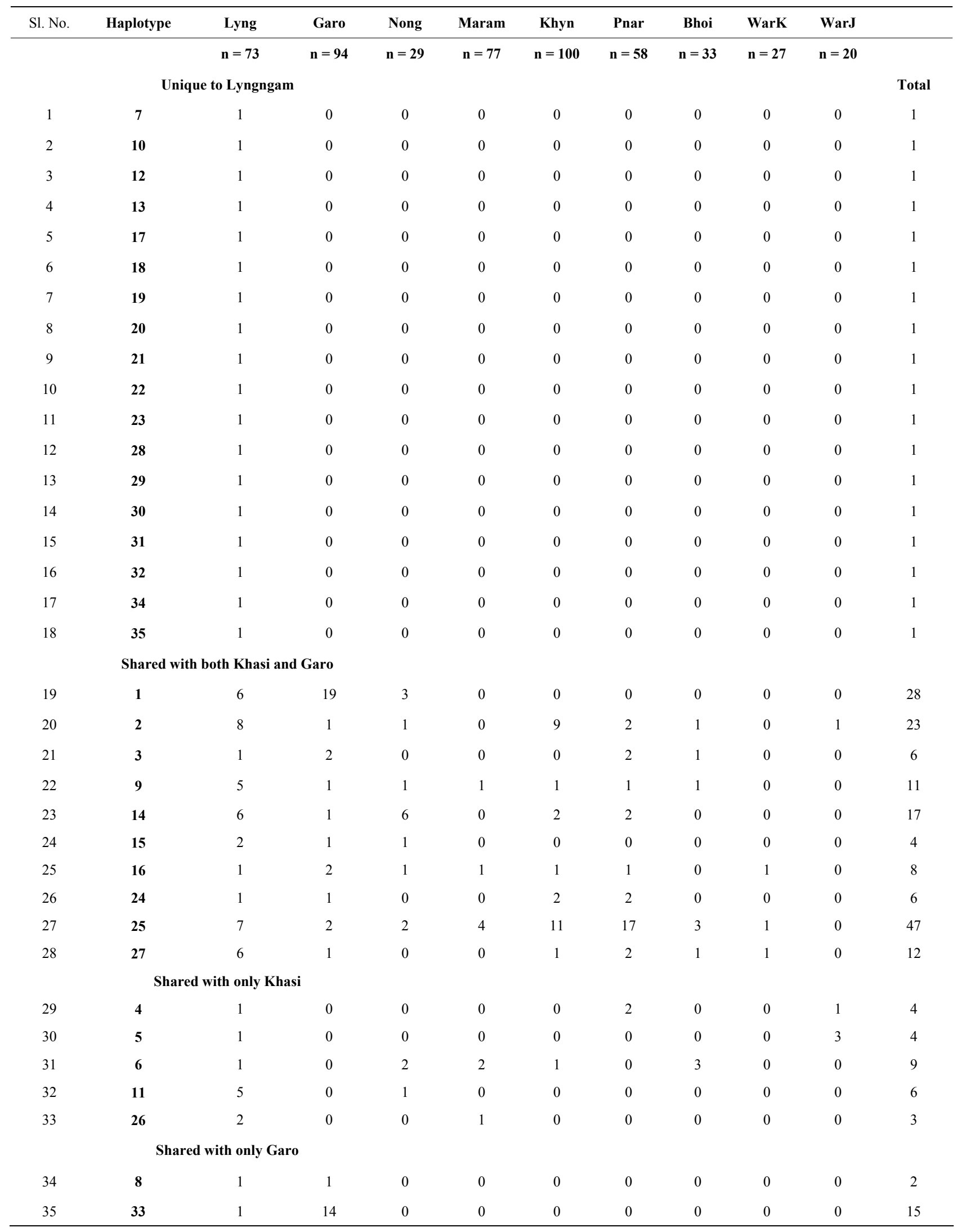




\section{B. T. LANGSTIEH ET AL.}

Table S4.

mtDNA HVRI haplotypes and their corresponding mutated positions for the Lyngngam population.

\begin{tabular}{|c|c|}
\hline Haplotypes & Mutated positions (nucleotide positions 16024 - 16400) \\
\hline Hap1 & $16081 \mathrm{~T}, 16168,16311$ \\
\hline Hap2 & 16168,16311 \\
\hline Hap3 & $16051,16168,16311$ \\
\hline Hap4 & 16168 \\
\hline Hap5 & 16111,16129 \\
\hline Hap6 & $16051,16172,16209,16239,16244,16352 \mathrm{del}, 16354$ \\
\hline Hap7 & 16316 \\
\hline Hap8 & $16093,16136,16223,16311$ \\
\hline Hap9 & $16223,16225,16234,16390$ \\
\hline Hap10 & $16037,16223,16225,16234,16354,16390$ \\
\hline Hap11 & $16223,16225,16234,16390$ \\
\hline Hap12 & 16057A, $16061 \mathrm{~A}, 16316$ \\
\hline Hap13 & $16043,16087 \mathrm{C}, 16095,16127,16223,16259,16324,16362$ \\
\hline Hap14 & $16093,16158,16223,16234,16362$ \\
\hline Hap15 & $16223,16311,16362$ \\
\hline Hap16 & $16187,16223,16362$ \\
\hline Hap17 & $16037,16187,16223,16362$ \\
\hline Hap18 & $16024 \mathrm{C}, 16025 \mathrm{~A}, 16028 \mathrm{~A}, 16029 \mathrm{G}, 16037,16043,16223,16274,16362$ \\
\hline Hap19 & 16223,16362 \\
\hline Hap20 & $16174,16223,16362,16365$ \\
\hline Hap21 & $16085 \mathrm{G}, 16223,16290,16305,16312 \mathrm{del}, 16319,16326,16331,16338 \mathrm{C}, 16343 \mathrm{~T}, 16349 \mathrm{C}, 16358,16360,16362 \mathrm{G}, 16368$, \\
\hline Hap22 & $16042,16055,16118 \mathrm{~T}, 16168,16311$ \\
\hline Hap23 & $16249,16288,16295,16304$ \\
\hline Нар24 & $16225,16234,16330 \mathrm{G}$ \\
\hline Hap25 & $16158,16223,16234$ \\
\hline Hap26 & $16093,16158,16234,16355 \mathrm{~A}, 16362 \mathrm{G}$ \\
\hline Hap27 & $16172,16183,16295,16296 \mathrm{~A}, 16324$ \\
\hline Hap28 & $16225,16234,16358 \mathrm{~A}, 16390$ \\
\hline Hap29 & 16024G, 16040A, 16078C, 16092A, 16223, 16261, 16274, 16311, 16357del, 16362 \\
\hline Нар30 & 16024del, 16025del, 16029G, 16223, 16225, 16234, 16390 \\
\hline Hap31 & $16162,16223,16225,16234,16390$ \\
\hline Hap32 & $\begin{array}{c}\text { 16024del, 16025del, 16028del, 16029del, 16032del, 16061A, 16071G, 16082A, 16083A, 16085G, 16088A, 16093, 16172, } \\
\text { 16183C, } 16324\end{array}$ \\
\hline Hар33 & 16024del, 16029G, 16032G, 16316 \\
\hline Hар34 & 16024del, 16132C, 16223T, 16362C \\
\hline Hap35 & 16024del, 16037, 16129, 16217, 16223, 16261, 16362 \\
\hline Hap37 & 16223,16362 \\
\hline Hap38 & $16093,16145,16223,16261,16311$ \\
\hline Нар39 & 16051,16168 \\
\hline Нар40 & $16158,16209,16234$ \\
\hline
\end{tabular}




\section{B. T. LANGSTIEH ET AL.}

Table S5.

mtDNA HVRII haplotypes and their corresponding mutated positions for the Lyngngam population.

\begin{tabular}{|c|c|}
\hline Haplotypes & $\begin{array}{l}\text { Mutated positions } \\
\text { (nps } 38-429)\end{array}$ \\
\hline Hap1 & $73,150,263,293,309$ insCT \\
\hline Hap2 & $73,150,152,153,263,309$ ins T \\
\hline Hap3 & $73,152,234,249 \mathrm{del}, 263,309$ ins T \\
\hline Hap4 & $73,152,153,309$ ins $\mathrm{T}$ \\
\hline Hap5 & 73, 152, 249del, 263, 309insT, 316 \\
\hline Hap6 & $73,152,263,309$ insC, 315 ins $C$ \\
\hline Hap7 & $73,151,152,263,309$ ins $\mathrm{T}$ \\
\hline Hap8 & $73,152,195,263,309$ ins T \\
\hline Hap9 & $73,146,263,309$ ins T \\
\hline Hap10 & $73,89,92,93,263,309$ ins T \\
\hline Hap11 & $73,92,93,263,309$ ins T \\
\hline Hap12 & $73,89,92,263,309$ ins T \\
\hline Hap13 & $73,94,263,309$ ins T, 368 \\
\hline Hap14 & 73, 199, 263, 309ins T \\
\hline Hap15 & 73, 199, 309ins T \\
\hline Hap16 & 73, 263, 309insCCT \\
\hline Hap17 & $42,73,263,293,309$ ins CT, 317, 320, 343, 345 \\
\hline Hap 18 & $32,40,57,60,63,73,263,309$ ins T, $363,367,376 \mathrm{C}, 384 \mathrm{~T}, 390$ \\
\hline Hap19 & $64,73,150,263,293,309$ ins CT, 317, 320G \\
\hline Hap20 & $64,73,150,199,309$ insT, 356insC \\
\hline Hap21 & 220A, 226G, 233A, 236A, 239A, 258A, 260A, 263, 270C, 272C, 280, 297C, 309insCCT, 329, 392G \\
\hline Hap22 & $73,150,199,309$ ins T \\
\hline Hap23 & $73,263,309$ ins T, 382A \\
\hline Hap24 & $73,152,263,309$ ins T \\
\hline Hap25 & $73,263,309$ insCT \\
\hline Hap26 & $73,195,263,309$ insCT \\
\hline Hap27 & 73, 199, 249del, 263, 309insT \\
\hline Hap28 & $73,263,278 \mathrm{C}, 280,309$ ins T \\
\hline Hap29 & $73,263,309$ insCT \\
\hline Hар30 & 73, 199, 249del, 263, 309insT, 382A \\
\hline Hap31 & 73, 199, 249del, 263, 309insT \\
\hline Hap32 & 73, 199, 263, 309insT \\
\hline Нар33 & 73, 207, 263, 293, 309insCT \\
\hline Нар34 & 71del, 73, 249del, 293 \\
\hline Hap35 & $125 \mathrm{G}, 148,150,309$ insCT \\
\hline
\end{tabular}

